\title{
The "reformation" of counselling
}

\author{
George A. Lotter \\ School for Ecclesiology \\ Potchefstroom University for CHE \\ POTCHEFSTROOM \\ E-mail: kwsgal@puknet.puk.ac.za
}

\begin{abstract}
The "reformation" of counselling

Although the Reformation took place some four hundred years ago, one area in which reformation is really needed today is the counselling of people. Since Wilhelm Wundt started the "study of the mind" in 1879, William James and Sigmund Freud followed and secular psychology gradually has developed to take the "front seat"; hence moving Biblical counselling, which has been practised since the times of the New Testament, to the "back burner". This development had been going on for the greater part of the 20th century, up to the publication of Competent to Counsel by Jay E. Adams in 1970. In the model for counselling suggested by Adams, the principles of the Reformation of the sixteenth century, Soli Deo Gloria, Soli Scriptura, Soli Fidei, Sola Gratia, etc. were again implemented in assisting and counselling people with personal and interpersonal problems. The epistomological and anthropological approach of secular psychology differs radically from that of Biblical principles, thus necessitating a new "reformation" of counselling. Within this new form counselling, inter alia, implies the following: the Word of God has its rightful place, sin has to be taken seriously and the work of the Holy Spirit should be recognised.

In this article it is proposed that the "reformation" of counselling was started by scholars with a Biblical Reformational approach and that this method of counselling followed the parameters of the Reformation of the sixteenth century. This "reformation" developed into a new direction in counselling and still continues today with fascinating new frontiers opening up for Biblical counselling.
\end{abstract}




\section{Introduction}

The hypothesis of this article is the following: secular psychology has usurped the field of traditional Biblical counselling. This development was counteracted by Jay E. Adams in the pioneering work Competent to Counsel which was published in 1970. In this book he stated his disillusionment with psychology and propogated the direction back to the principles of the Reformation, like inter alia the sole authority of Scripture, the justification of faith in Christ alone and the priesthood of all believers. Looking back on this development, it indicates nothing short of a "reformation" of counselling in the strictest sense of the word.

\section{Development and the influence of secular psychology}

Since the start of the first laboratory for the scientific study of the mind in 1879 and the work of William James and Sigmund Freud (Jordaan \& Jordaan, 1992:19-23) the growth of psychology as a discipline and as a way to help people in therapy, has been phenomonal. It is as if people in trouble "shifted" their hope to psychology and man-made wisdom (MacArthur, 1994:7) whereas in the past they relied on the pastor, the priest and Biblical solutions. As Bulkley (1997:50) states it bluntly:

We have accepted myths of expertise, believing that psychology and psychiatry are able to look deep into the soul and unravel the mysteries of the human motivations, while doubting the Scripture's power to judge 'the thoughts and attitudes of the heart' (Heb. 4:12).

The impact of psychology is inter alia the "No-Book approach", which

... leaves the counseling community with no book, no authority, no absolute dependable source of truth, and no normative standard against which to measure the countless theories and models profferred today in the worlds of psychology and counseling (Bookman, 1994:81).

This "new" trust in psychology became so strong that "... secular psychologies claimed the turf of counseling expertise and of insight into human nature" (Powlison, 1994:45) and the kind of Biblical counselling since the time of the New Testament was in many cases replaced by secular psychology and psychology-related therapies. Vitz (1994) named the title of his book Psychology as Religion. The Cult of Self-Worship while he himself is a professor of psychology at New York University! In this book, Vitz (1994:96) shows how today's humanistic "selfism" (as he calls it) has roots in the teachings of Ludwig Feuerbach and a long line of humanistic theorists who followed him with one thing in common: arguments against the divinity of Christ and the existence of God. The 
general premisse is that all theology be resolved in anthropology. This view has been continued to this very day with postmodernity in full swing (cf. Thompson, 2000:29). Already in 1993 Worthington (1993:271) summarised the focus of the nineties thus:

Postmodernism will push people toward individually understood, psychologically-based religions. Many will come to the psychotherapist to try to discover meaning in life rather than come to the pastor and the church. The therapist will increasingly function as a secular priest.

As pastoral counsellor one often experiences the resistance of psychologists against pastoral counselling or to be more precise, Biblical counselling as a whole. A good example is found in the case of Richard Ganz who lost his job at a psychiatric hospital because of his open Christian therapy (Ganz, 1995:18). MacArthur (1994:6) also relates a court case that landed in the American Supreme Court where the church was blamed for someone's suicide after Christian counselling. The argument was that Biblical counselling is not "professional" and that counselling should only be done by trained professionals in psychology (MacArthur, 1994:5).

The preliminary conclusion of the first part of this article indicates that psychology not only exalted itself to high levels of acceptance but was also hailed by others as the know-all and fix-all of all personal and interpersonal problems as Powlison (1994:46) calls it: "The huge and dominating outer circle (of) secular psychology". Verhoef (2000:99 ff.) indicates how all these theories not based on the Bible, are predominant in the theory of counselling and therapy.

It was important to show the development and influence of (secular) psychology up to recent times to get an overview of the impact of it. The bottom line of this view is the dependence on human wisdom and the fact that cognition of the work of God and all the principles of the Reformation (as will be pointed out) are not taken heed of and are regarded as of no avail.

\section{The guiding principles of the Reformation}

In dealing with the development of secular psychology (which is a definite movement away from the principles of the Bible) it is necessary to give a short overview of the principles of the Reformation in order to indicate that what Jay Adams did in counselling was something similar to the Reformation of the 16th century (Hindson, 1979:28-39). One of the results of the Reformation is that man's relation to God has been rephrased to a more Biblical orientation (Kok, 1996:123) - a result that 
has important consequences on the view of man (Van der Walt, 1994: 155) and consequently on the counseling of people (Hindson, 1979:33). It is generally accepted that the Reformation had three pillars: Sola Scriptura, Sola Fides and Sola Gratia (Lindberg, 1996:71).

A quote by Mohler (2000: 2) gives a summary of the Leitmotif of the Reformation:

The central tenet of Calvinism is the sovereignty of God. This is the starting point and the highest principle of Reformed theology. Calvinism is God-centered and draws its understanding of God directly from His self-revelation in Scripture. The God revealed in the Bible is the sovereign Creator, Ruler, and Redeemer. His omnipotence, omniscience, and governance over all things set this God of the Bible apart from all false Gods.

According to Atkinson (1996:696-699) five leading principles directed the Reformation:

- Justification by faith alone

- The sole authority of Scripture

- Rejection of any claim to political power (like the Roman Church propagated)

- The priesthood of all believers

- Acceptance of two and not seven sacraments

The Reformation had a profound influence on the thinking of people in many spheres, and consequently also the way man was viewed, hence determining the way counselling was done. If, for instance, a counsellee does not take the authority of Scripture seriously, he/she will be going his/her own way and real change according to Scriptural principles will not be brought about. The principle of the priesthood of all believers also has a far-reaching effect on the way counselling will be done: counsellees' own responsibility should get attention in all counselling. Justification by faith alone is a strong "tool" to deal with people having problems with self-esteem. It can be a separate study on how the principles of the Reformation of the 16th century changed the counselling scene.

Following the Reformation, different creeds were formulated on the basis of the fresh, albeit original way of understanding Scripture. The Reformed creeds formulated in Europa were mainly the Canons of Dordt, the Belgic Confession and the Heidelberg Cathechism, while in the Anglo-Saxon world the Westminster Confession was the leading creed 
focusing on the Sola Scriptura (Powlison, 1994:86). In America, where Adams worked and wrote Competent to Counsel in 1970, the Five Points of Calvinism became the standard from which many American Calvinists got their brand of Calvinism which goes back to the Synod of Dordt (1618-1619) (Steele \& Thomas, 1975:14). These Five Points form the acronym TULIP (Total depravity, Unconditional election, Particular redemption, Efficacious grace and Perseverance of the saints) which became very popular in everyday language. Jay Adams even wrote a treatise on Counseling and the Five Points of Calvinism (1981).

\section{Adams' "reformation" of counselling}

As was indicated earlier, the "false Gods" (Mohler, 2000:2) which were served, could also include secular psychology (cf. MacArthur, 1994:6; Vitz, 1994:96). According to Vitz (1994:128) - who calls psychology, where selfism is at the centre, a "religion": "[t]o worship one's self (in selfrealization) or to worship all humanity is, in all Christian terms, simply idolatery operating from the usual motive of unconscious egotism" (italics by the author). It was against this "idolatery" that Adams moved and "penned his 95 statements to the church door" (like Marten Luther did) by way of speaking (cf. Anon., 1995:1374). Adams was also in reaction to Hiltner who had a positive view on psychology, psychiatry, anthropology and other sources and stated "... its riches are such that no thoughtful person can set them aside" (Hiltner, 1958:25). According to Heyns and Pieterse (1990:89) Hiltner "made an outstanding contribution" to Practical Theology (which Hiltner calls "Pastoral Theology").

Jay E. Adams was 41, a Presbyterian pastor and seminary professor (Powlison, 1996:1) when he came to what he calls "some large convictions" (Adams, 1970:xvi). He realised that the people he was counselling had unforgiven and unaltered sinful behaviour and due to that he was driven " ... back to the Bible to ask again: "What do the Scriptures say about such people and the solution to their problems?'” (Adams, 1970:xvi). It seems as if Adams struck upon the very nerve of what was wrong with secular psychology: the human-focusedness and the fact that the God of the Bible (and therefore the guidance of the Bible) had been obliterated from all therapy to people in real need of counselling. He concurred: "It is amazing how much the Bible has to say about counselling, and how fresh the biblical approach is" (Adams, 1970:xix). It is interesting to note that Adams delivered a speech in 1996 at a conference of the Concerned Presbyterians in Greenville with the title "How to bring Reformation to the church" (Pelser, 1996:33). 
Unknowingly, he started another reformation in 1970, this time in Christian counselling. Adams called his way of counselling "Nouthetic counseling" which consists of three basic elements:

- A problem addressed by confrontation.

- Training by word of mouth.

- Person-to-person verbal confrontation (Adams, 1970:44-46).

A short summary is given by Adams himself: "Nouthetic confrontation, in its biblical useage, aims at straightening out the individual by changing his patterns of behaviour to conform to biblical standards" (Adams, 1970:46). In 1995 Adams repeated what his view was on what the proper way is to construct a biblical counselling system by beginning with the following fundamental presuppositions (Adams, 1995:25): “... the Bible is the inerrant Source and truth from God concerning life and godliness, and God provided in the Bible all that one needs for life and godliness. These presuppositions underlay all else".

In 2001 Adams formulates it in the following way:

The three ideas found in the word nouthesia are Confrontation, Concern and Change. To put it simply, nouthetic counseling consists of lovingly confronting people out of deep concern in order to help them make those changes that God requires.

By confrontation we mean that one Christian personally gives counsel to another from the Scriptures. He does not confront him with his own ideas or the ideas of others. He limits his counsel strictly to that which may be found in the Bible, believing that 'All Scripture is breathed out by God and useful for teaching, for conviction, for correction and for disciplined training in righteousness in order to fit and fully equip the man from God for every good task' (2 Timothy $3: 16,17)$. The nouthetic counselor believes that all that is needed to help another person love God and his neighbor as he should, as the verse above indicates, may be found in the Bible.

By change we mean that counseling is done because there is something in another Christian's life that fails to meet the biblical requirements and that, therefore, keeps him from honoring God. By concern we mean that counseling is always done for the benefit of the counselee (italics by author) (Adams, 2001:2).

Powlison (1996:3) gives a summary of Adams's work which he calls the "traditional Christian message":

First, because 'Man's greatest need is forgiveness', the forgiving grace of Jesus Christ was essential to solving problems in living. 
Adams believed that God worked within the human personality, and that those who were forgiven would also be helped by the Holy Spirit to alter patterns of thinking, feeling and behavior. Second, as thankful recipients of such grace, 'human beings should look like Jesus Christ'. Thus Adams defined the change process, again frankly and in theological terms, as 'progressive sanctification'. Both normal and extreme range sin and misery would find 'progressive' resolution as people began living according to the pattern of 'faith and practice' taught in the Bible.

The above-mentioned quote states convincingly what the "reformation" of counselling inter alia implies:

- the Godward face of Biblical counselling (cf. Bookman, 1994:154);

- the realisation of $\sin$ as the cause of all problems (cf. Schalesky, 1995:38);

- only Christ can bring lasting healing (cf. Collins, 1997:27);

- man is depraved and needs the forgiving grace of God (cf. Hazard, 1998: 25);

- the work of the Holy Spirit in counselling is important (cf. Lotter, 1993:52);

- the sufficiency of the Bible (cf. Welch, 1997:81);

- the need for "real change" (cf. McGee, 1997:138).

The impact of Adams's Competent to Counsel was tremendous: it was translated in about 15 languages and up to 10000 copies of it were sold per year during the first half of the 1990's (Powlison, 1996:92), thus clearly indicating not only that people need something "solid" Biblical and not humanistic-orientated, but also that secular psychology has failed in many instances in bringing relief to distressed people.

Criticism however, did not stay out and many counsellors, other therapists and psychologists attacked Adams on his stand for going "back to the Bible". Heitink (1984:45) warns that Adams does not escape the dangers of biblisism while Louw (1998:30) indicates four major problems concerning Adams' approach:

- Conversion cannot be employed as a therapeutic method.

- Soteriology and the doctrine of creation are separated.

- A dualism is created between matter and spirit.

- The Scripture cannot be applied to all human problems. 
Even Adams's approach, advocating the reinstating of the importance of the sovereignty of God and stressing the depravity of the human being and the need for salvation, is also criticised (cf. McMinn, 1996:168). Bulkley (1997:14) mentions the "Nothing Butterists" referring to the three solas which were discussed in 3 (above): "Nothing but Grace, Nothing but Faith, Nothing but the Word" and also quotes a prominent Christian (sic) psychiatrist who states that those who disagree with psychiatry and psychology are "pharisees, hypocrits and legalists". Most propably he refers to Adams who takes a definite stand against psychiatry and psychology (Adams, 1973:33).

Muller (1996:28) briefly refers to Adams's and Thurneysen's prophetickerugmatic approach by which admonishing is indicated as the way to bring someone to a life of meaning, and suggesting that a narrative approach is better.

It is therefore clear that critisism of many aspects of Jay Adams's nouthetic counselling has been lodged and should be considered carefully. Some of these points of criticism should be taken seriously especially when they show a one-sidedness, for instance when the findings of research undertaken in the field of psychology are ignored completely. Perhaps more could be made of "common grace" (Vorster, 2001:13) in the sense that God can use secular psychologists to "stumble over the truth" (seeing something in reality which really exists).

Another development that had already started before Adams, but intensified since Adams made his stand on counselling which should be "Reformed" (meaning adhering to the principles of the Reformation) (Adams, 1973:34), is the whole issue of the integration of theology and psychology (cf. Sorenson, 1996:26-30; Joubert, 1999:241 ff.; Verhoef, 2000:241). It, however, lies beyond the focus of this article but should be mentioned because of its importance in the contemporary field of counselling.

Before Adams formulated the concept of nouthetic counselling (1970), other models of counselling were also outlined, like that by Hiltner (1958:28) which was followed by many more. See the overview of Heitink (1999:112-123) - someone who has a grip on relevant and counselling-focused developments on different continents. However, no other model adheres so strictly to Biblical guidelines than Adams's model. He himself verbalises the core requirement of this model thus: "... the Christian counselor must have an ever-increasing understanding of Scripture that covers a wide variety of issues" (Adams, 1995:51). 
Other models can be enriching and should be taken cognisance of, since they widen the whole scope of counselling and the underlying principles of Practical Theology.

\section{The effects of the "reformation" of counselling}

What was started by Adams in 1970, had a world-wide effect. Students from around the world went to study at Westminster Theological Seminary (WTS) where Adams lectured for many years and later became Visiting Professor (Powlison, 1996:100). Adams also founded the Christian Counseling and Educational Foundation (CCEF) in Philadelphia co-operating with the Westminster Theological Seminary. At this seminary Adams's focus of counselling is taught, namely that "the gospel [should speak] with great depth and breadth to all the problems of life"... "and Westminster graduates are replicating this approach to counseling in their work" (Anon., 2001:2).

As a result of this points of departure in the field of counselling new frontiers and possibilities opened up: in America the NANC (National Association of Nouthetic Counselors) was formed (Powlison, 1996:118, cf. NANC, 2001) with the following mission:

The mission of NANC is to pursue excellence in Biblical counseling by conducting a comprehensive certification process, providing extensive training opportunities, and networking pastors, laymen, and missionaries nationally and internationally.

Students from many parts of the world enrolled for counselling courses at Westminster Theological Seminary, also pastors from different South African congregations. Postgraduate studies were also undertaken by students following Adams and his school of thought (cf. Combrink, 1986; Powlison, 1996). It is evident that scholars dealing with any aspect of Christian counselling cannot ignore the work and influence of Adams (cf. Houston et al., 1999:238).

The relevance of Adams' views for this programme is inter alia underpinned by the basic Biblical foundation utilised for 20th century counselling (cf. Tiemensma \& Venter, 1990; Kruger \& Venter, 1996; Lartz, 1999). A whole generation of Biblical scholars, students and pastors has been trained and versed in the thinking of Jay E. Adams and Westminster Theological Seminary still attracts students from all over the globe, due to this emphasis on Biblical counselling. 


\section{The road ahead?}

Following the publishing of Competent to Counsel in 1970, many new venues opened for Biblical counselling in line with Jay Adams' views (as indicated in 5 above). Apart from the critisism of biblisism, behaviourism and "nothing buttery", works suggesting improvements on Adams's model have been published. Pelser (1996:2) for instance, critisises Adams for not making enough of the "in-Christ" formula and suggested that his work could have been enriched by this.

Other second and third generations "Adams-ists" opened the scope of Biblical counselling to areas like co-dependency (Welch, 1997), demonic and spiritual warfare (Powlison, 1997 \& Powlison et al., 1998), interpersonal communication (Tripp, 2001) and the defence of Biblical counselling (Johnson, 2001). Welch (2001) addresses another issue that has been neglegted by nouthetic counsellors in die past: brain disorders.

A lot more could be written about Biblical anthropology (cf. Verhoef, 2000) and the use of Scriptures in counselling regarding the latest trends in hermeneutics and the use of the narrative approach in counseling (cf. Vermeulen, 1999; Pretorius, 2000).

\section{Conclusion}

In this article it was proposed that a "reformation of counselling" was needed as secular psychology transgressed this field of and opposed Biblical counselling. Secular psychology is actually foreign to everything the Reformation of the 16th century stood for. In 1970 Jay Adams started something that was nothing less than a "new reformation" by advocating going back to the principles of the Reformation and applying them to counselling. This trend has meanwhile grown into a new "school" in counselling which is still developing. Within this specific kind of counselling the Word of God is taken seriously and the principles of the Reformation in general are pursued. As a result of this development new dimensions in counselling are opening due to the growth of Biblical counselling.

\section{Bibliography}

ADAMS, J.E. 1970. Competent to counsel. Phillipsburg, NY : Presbyterian \& Reformed Publishers.

ADAMS, J.E. 1973. The Christian counselor's manual. Grand Rapids, Mi : Baker Book House.

ADAMS, J.E. 1981. Counseling and the five points of Calvinism. Phillipsburg, N.Y : Presbyterian \& Reformed Publishing.

ADAMS, J.E. 1995. Teaching to observe. The counselor as teacher. Woodruff, SC : Timeless Texts. 
ADAMS. J.E. 2001. Nouthetic counseling is not new. [Web:]

http://www.nanc.WHATISNOUTHETICCOUNSELINGpopupA.shtml [Date of access: April 14, 2001].

ANON. 1995. Reformation. (In Cross, F.L. \& Livingston, E.A., eds. Oxford Dictionary of the Christian Church. Oxford : Oxford University Press. p. 1374-1375.)

ANON. 2001. Preaching and counseling traditions at Westminster. Westminster Theological Seminary Bulletin, 41(1):2, Spring.

ATKINSON, J. 1996. Protestantism. (In Clark, P.B. \& Linley, A., eds. Dictionary of Ethics, Theology \& Society. London : Clark. p. 695-699.)

BOOKMAN, D. 1994. The scriptures and Biblical counseling. (In MacArthur, J.F. \& Mack, W.A., eds. Introduction to Biblical counseling. A basic guide to the principles and practice of counseling. Dallas : Word Publishing. p. 63-97.)

BULKLEY, E. 1997. Can counseling be Christian? Have we sold our birthright? Christian Counseling Today, 5(1):14, 49-51.

COLLINS, G.R. 1997. Does faith heal? Christian Counseling Today, 5(3):24-27.

COMBRINK, V. 1986. Skrifgebruik in Pastoraat: Die standpunt van Jay E. Adams. Potchefstroom : PU vir CHO. (Wetenskaplike bydraes van die PU vir $\mathrm{CHO}$, Reeks A: Geesteswetenskappe, nr. 59.)

GANZ, R. 1995. Confession of a psychological heretic. The Journal of Biblical Counseling, 13(2):18-22, Winter.

HAZARD, D. 1998. Truly transformed. Discipleship Journal, 18(2):22-27, Mar/Apr.

HEITINK, G. 1984. Pastoraat als hulpverlening. Inleiding in de Pastorale Theologie en Psychologie. Kampen : Kok.

HEITINK, G. 1999. Practical Theology. History. Theory. Action domains. Manual for Practical Theology. Grand Rapids, Mi : Eerdmans.

HEYNS, L.M. \& PIETERSE, H.J.C. 1990. A primer in Practical Theology. Pretoria : Gnosis.

HILTNER, S. 1958. Preface to Pastoral Theology. The ministry and theory of shepherding. New York : Abingdon Press.

HINDSON, E.E. 1979. Biblical view of man. The basis for nouthetic confrontation. The Journal of Pastoral Practice. A Professional Periodical for Ministers, 3(1): 33-58.

HOUSTON, B.M., BUFFORD, R.K. \& JOHNSON, W.B. 1999. Distinctive components and perceived sources of gain in Christian Counseling. Journal of Psychology and Christianity, 18(3):238-253.

JOHNSON, E., ed. 2001. Psychology and Christianity: Four Views. Philadelphia : P \& R Publishers.

JORDAAN, W. \& JORDAAN, J. 1992. Mens in konteks. Johannesburg : Lexicon Uitgewers.

JOUBERT, N.L. 1999. Die ontwerp en evaluering van 'n Bybelsgefundeerde terapieprogram vir 'n gemeente. Potchefstroom : PU vir CHO. (Ph.D.-Proefskrif.)

KOK, J.H. 1996. Patterns of the Western mind. A Reformed Christian perspective. Potchefstroom : PU for CHE. (Scientific Contributions, Series F2, no. 64.)

KRUGER, F.S. \& VENTER, C.J.H. 1996. Selfliefde: 'n Skrifondersoek met die oog op omlyning van basisteoretiese perspektiewe vir die pastoraat. In die Skriflig, 30(3):365-383, Sept.

LARTZ, D. 1999. Die pastorale berading aan die jaloerse huweliksmaat. Potchefstroom : PU vir CHO. (M.A.-verhandeling.)

LINDBERG, C.1996. The European Reformations. Oxford : Blackwell.

LOTTER, G.A. 1993. Die werk van die Heilige Gees in die gelowiges volgens 2 Korintiërs. Potchefstroom : PU vir CHO. (Th.D.-proefskrif.) 
LOUW, D.J. 1998. A pastoral hermeneutics of care and encounter. A theological design for a basic theory, anthropology, method and therapy. Cape Town : Lux Verbi.

MacARTHUR, J.F. 1994. Rediscovering Biblical counseling. (In MacArthur, J.F. \& Mack, W.A., eds. Introduction to Biblical counseling. A basic guide to the principles and practice of counseling. Dallas, Tx : Word Publishing. p. 3-20.)

McGEE, R.S. 1997. The search for significance. Houston, Tx : Rapha Publishing.

McMINN, M.R. 1996. Psychology, theology and spirituality. Wheaton, II : Tyndale.

MOHLER, R.A. 2000. The Reformation of doctrine and the renewal of the church: $A$ response to Dr. William R. Estep. [Web:]

http://www.reformedreader.org/rdrc.htm [Date of access: 31 July 2000].

MULLER, J. 1996. Om tot verhaal te kom. Pastorale gesinsterapie. Pretoria : RGN. NANC (RGN Studies in Praktiese Teologie.)

see NATIONAL ASSOCIATION OF NOUTHETIC COUNSELORS

NATIONAL ASSOCIATION OF NOUTHETIC COUNSELORS. 2001. Our mission. [Available on the Internet:] http://www/nanc.org.nancOURMISSION.shtml. [Date of access: 14 April 2001].

PELSER, D.B. 1996. Die in-Christus formule in Romeine 3:21-8:39 en die toepassing daarvan op die beradingsmodel van Jay E. Adams. Potchefstroom : PU vir CHO. (M.A.-verhandeling.)

POWLISON, D., STRINGHAM, N., TROXEL, A.B., TAN, S.Y. \& MUINDE, P. 1998. Demonic and spiritual warfare. Christian Counseling Today, 6(2):40-47.

POWLISON, D.A. 1994. Biblical counseling in the twentieth century. (In MacArthur, J.F. \& Mack, W.A., eds. Introduction to Biblical counseling. A basic guide to the principles and practice of counseling. Dallas, Tx : Word Publishing. p. 44-62.)

POWLISON, D.A. 1996. Competent to counsel? The history of a conservative protestant anti-psychiatry movement. Philadelphia : University of Pennsylvania. (Ph.D.-Dissertation.)

POWLISON, D.A. 1997. Power encounters. Reclaiming spiritual warfare. Grand Rapids, Mi : Baker.

PRETORIUS, J.P. 2000. Kinderberading: 'n Bybels-narratiewe model. Potchefstroom : PU vir CHO. (M.A.-verhandeling.)

SCHALESKY, M.M. 1995. Remember Eve. Discipleship Journal, 15(1):36-39, Jan/Feb.

SORENSON, R.L. 1996. The faces of integration. Christian Counseling Today, 4(1): 26-30, Winter.

STEELE, D.N. \& THOMAS, C.C. 1975. The five points of Calvinism: Defined, defended, documented. Philadelphia, $\mathrm{Pa}$ : Presbyterian \& Reformed Publishing.

THOMPSON, G.G. 2000. Proclaiming the Gospel to postmodernists. Potchefstroom : PU vir CHO. (Ph.D.-thesis.)

TIEMENSMA, E.J. \& VENTER, C.J.H. 1990. Riglyne vir pastorale huweliksorg binne die konteks van gemeente-opbou. In die Skriflig, 24(4):333-351, Desember.

TRIPP, P. 2001. War of words. Philadelphia : P \&R publishing.

VAN DER WALT, B.J. 1994. The liberating message. A Christian worldview for Africa. Potchefstroom : PU for CHE. (Scientific Publications of the PU for CHE. Series F3, no. 44.)

VERHOEF, C.G. 2000. Die noodsaak van 'n Bybelse mensbeskouing in berading: enkele snitte uit die Skrif en die praktiese implikasies daarvan. Potchefstroom : $\mathrm{PU}$ vir CHO. (M.A.-verhandeling.) 
VERMEULEN, P.J. 1999. Pastorale dimensies van sekere Ou-Testamentiese gelykenisse. Potchefstroom : PU vir CHO. (Ph.D.-proefskrif.)

VITZ, P.C. 1994. Psychology as religion. The cult of self-worship. (Second Edition.) Grand Rapids, Mi : Eerdmans.

VORSTER, J.M. 2001. 'n Christelike teorie van menseregte. In die Skriflig, 35(1):124, Maart.

WELCH, E.T. 1997. When people are big and God is small. Overcoming peer pressure, co-dependency, and the fear of man. Phillipsburg, $\mathrm{Pa}: \mathrm{P} \& \mathrm{R}$ Publishing.

WELCH, E.T. 2001. Blame it on the brain. Philadelphia, Pa : P \& R Publishing.

WORTHINGTON, E.L. 1993. Psychotherapy and religious values. Grand Rapids, Mi: Baker.

Kernbegrippe:

Bybelse berading pastorale berading Reformasie van die 16 de eeu

Key concepts:

Biblical counselling pastoral counselling

Reformation of the 16th century 


\section{Boekbekendstelling}

\section{'n Verkenning van die koninkryksidee ${ }^{1}$}

VAN WYK, J.H. 2001. Etiek en eksistensie in koninkryksperspektief. Potchefstroom : Potchefstroomse Teologiese Publikasies. Prys: R100. ISBN 0-86955-130-2.

\section{P.J. de Bruyn \\ Potchefstroom}

Dit is vir my 'n voorreg om 'n boek soos hierdie bekend te stel. Om net oor hierdie boek te praat en nie ook oor die skrywer nie is egter 'n moeilike opgawe, want die boek is tog die produk van 'n skrywer, en in die boek ontmoet jy die skrywer op elke bladsy.

\section{Die titel}

Die titel van die boek, Etiek en eksistensie in koninkryksperspektief, verdien nadere toeligting. In die verlede het telkens geblyk dat prof. Van Wyk 'n besondere belangstelling het vir die koninkryk van God - 'n belangstelling wat tot 'n groot mate by hom gewek is deur wyle prof. W.J. Snyman. Prof. Van Wyk het dikwels gesê dat hy dit vreemd vind dat daar in die bekendste Dogmatiekhandboeke nie ook 'n locus/afdeling oor die koninkryk van God is nie. Hierdie belangstelling by hom om etiese vraagstukke ook te besien in die lig van die koninkryk van God is ook deur andere raakgesien. Op die titelbladsy verskyn ' $n$ aanhaling van 'n uitspraak van prof. J.A. Heyns oor die skrywer se hantering van die etiek. Heyns sê: "Indien die skrywer daartoe sou kom, wat ons almal hoop, dat hy 'n omvattende etiek gaan skrwye, sal dit goedskiks 'n koninkryksetiek genoem kan word". Hierdie besondere aksent op die betekenis van die koninkryk van God vir die etiek, kom ook - soos 'n mens kan verwag duidelik in hierdie boek na vore. Hy bepleit daarin selfs 'n Wysbegeerte van die koninkryksidee (p. 206).

1 Geleentheidswoord by die bekendstelling van bogenoemde publikasie van prof. J.H. van Wyk op 13 Maart 2001. 


\section{Erkenning aan vyf teoloë}

In die boek word besondere erkenning verleen aan vyf teoloë van wie Van Wyk sê dat hy baie geleer het en vir wie hy 'n bepaalde affiniteit ontwikkel het. Hulle is G.C. Berkouwer, J.A. Heyns, W.D. Jonker, W.J. Snyman en W.H. Velema.

\section{Samestelling}

Die boek is grotendeels 'n samevoeging van artikels wat in geakkrediteerde tydskrifte verskyn het. Die artikels is sinvol georden en in sewe afdelings ingedeel.

\section{Inhoud}

\section{- Inleidende artikels}

In die eerste afdeling "Inleidende artikels", handel hy oor die moraliteitskrisis, verduisterde selfinsig as morele probleem, skuldbelydenis in teologiese perspektief en die betekenis van 'n Skrifgefundeerde antropologie vir die pastoraat.

\section{- Etiese stemme}

In hierdie afdeling word gefokus op aspekte van die etiese beskouings van sekere teoloë en filosowe. Hier kan onder andere in drie hoofstukke die resultaat van Van Wyk se belangstelling in en navorsing oor Augustinus gesien word. Vir hom is die studie oor Augustinus baie belangrik omdat hy ook 'n teoloog van Afrika was, maar veral omdat sy bydrae as teoloog buitengewoon groot is. Hy sê: "Soos die berg Kilimandjaro bo die Afrikaanse landskap uittroon, so troon die figuur van Augustinus uit bo die teologiese landskap van Afrika en die Westerse wêreld" (p. 72). Ander persone aan wie hy in die afdeling aandag gee, is Dietrich Bonhoeffer, H.G. Stoker en Johan Heyns.

\section{- Mediese etiek}

Uiters aktuele sake soos vigs, kloning en die hedendaagse voortplantingstegnologie kom in hierdie deel aan die orde. Hier word ook besin oor die betekenisvolle vraag: Is daar 'n konflik tussen wat kan en wat mag?

\section{- Seksuele etiek}

In hierdie afdeling word die aandag gevestig op die uiters belangrike saak van seksuele etiek in Afrika-konteks. Die skrywer sluit in hierdie afdeling aan by en brei uit op die waardevolle werk van H.L. Pretorius: Swartman, seksualiteit en sending wat reeds in 1977 verskyn het. 


\section{Politieke etiek}

In hierdie afdeling word oorweging geskenk aan die Marxistiese etiek en aan vrede en vryheid as temas in die sosiale etiek. Die etiek van vrede is natuurlik 'n onderwerp waarvoor die outeur besondere belangstelling het en ook sy proefskrif daaroor geskryf het. Die problematiek waarvoor die moderne mens staan, dui hy aan met 'n aanhaling van Lester Pearson wat in 1957 al gesê het: "We prepare for war like precocious gaints and for peace like retarded pigmees".

\section{- Arbeidsetiek}

Hoewel daar al baie oor die arbeidsetiek geskryf is, word hier 'n oorspronklike teologies-etiese beoordeling van arbeid vir die hedendaagse Christen aangebied. Eers word die vernaamste persepsies op arbeid verduidelik en daarna word die sentrale perspektiewe van 'n Christelike arbeidsetiek aangedui. In die lig daarvan beoordeel hy dan hedendaagse arbeidsprobleme.

\section{- Etiek en eskatologie}

Die boek eindig heel gepas met 'n afdeling en 'n hoofstuk waarin die dogmatiese en etiese implikasies van die verwagting van 'n nuwe hemel en 'n nuwe aarde aangedui word.

\section{Enkele opvallende kenmerke}

- Eerstens word 'n mens getref deur die verantwoorde hantering van en beroep op die Skrif. Van 'n fundamentalistiese en 'n kritisistiese Skrifhantering is daar geen tekens in die boek te vinde nie. Verder word voortdurend in die uiteensettings en beoordelings verreken dat Jesus Christus die middelpunt en hoogtepunt van God se openbaring aan die mens is (Heb. 1:1-2) en word nie buite Christus om (en die Heilige Gees, Hand. 15:28) met die Skrif omgegaan nie (p. 430).

- Tweedens is die perspektief vanuit die koninkryk van God opvallend en tegelyk besonder waardevol. Aangesien ek reeds daarna verwys het, gaan ek nie weer daarop in nie.

- Die boek het verder 'n besondere Afrika- en selfs 'n Suid-Afrikagerigtheid. 'n Persoon soos Velema sê in Theologia Reformata (1997, 40(3):183) dat 'n opvallende kenmerk van Van Wyk se geskrifte die volgende is: "openheid voor de zamenleving en de kring waartoe hij zelf behoort".

- Verder word 'n mens getref deur die skrywer se deeglike kennis van sake. Hy probeer altyd om soveel as moontlik literatuur oor 'n 
onderwerp te bekom en dit dan indringend te bestudeer. Velema verwys in 'n artikel in die boek wat aan wyle prof. J.A. Heyns opgedra is na 'n artikel van J.H. van Wyk en voeg dan heel gepas by: "... met, zoals wij van hem gewend zijn, een uitvoerige literatuurverwijzing" (C.J. Wethmar \& C.J.A. Vos. 1988. 'n Woord op sy tyd. p. 197).

- In hierdie boek word nie geskroom om kritiek - en selfs skerp kritiek uit te spreek nie, maar dit is deurgaans wetenskaplik en verantwoorde kritek. Daarby word die kritiek in 'n Christelike gesindheid en met pastorale bewoënheid uitgespreek.

- Ook uit hierdie boek blyk dat die skrywer 'n besondere gebalanseerde mens en wetenskaplike is. Wat hy self van W.D. Jonker sê in die bundel wat aan hom opgedra is, kan myns insiens ook van Van Wyk gesê word, naamlik: "Hy is 'n soeker na ortodoksie sonder ortodoksisme, piëteit sonder piëtisme, liberaliteit sonder liberalisme, rasionaliteit sonder rasionalisme en humaniteit sonder humanisme" (P.J. Theron \& J. Kinghorn. 1989. Koninkryk, kerk en kosmos. p. 84).

- 'n Besondere kenmerk van al Van Wyk se geskrifte, en derhalwe ook van hierdie een, is dat hy verstaanbaar skryf. 'n Mens sukkel nie om te verstaan wat hy bedoel nie. Dit is 'n besondere genadegawe wat hy ontvang het en wat hy ook effektief gebruik.

\section{Samevatting}

Na my oordeel is dit 'n uiters belangrike boek oor aktuele sake. 'n Mens word daardeur geestelik verryk en nuwe perspektiewe word vir jou geopen. Sterk oorweging behoort daaraan geskenk te word om hierdie boek in Engels te laat vertaal en dit dan ' $n$ voorgeskrewe boek vir teologiese studente te maak. 


\title{
Respons
}

\section{Die etiek: om in die oomblik van waarheid die regte rigting aan te dui Respons op die bekendstelling van Etiek in eksistensie in koninkryksperspektief}

\author{
J.H. van Wyk \\ Potchefstroom
}

\section{Dankwoorde}

'n Skrywer se eerste en oorweldigende indruk by 'n geleentheid waar sy publikasie bekend gestel word, is dié van groot dankbaarheid, en wel ten opsigte van 'n hele aantal persone en instansies. ${ }^{1}$

Ons groot dank is egter teenoor die grote God wat mense in sy diens wil gebruik. Dit is 'n uitnemende voorreg en 'n groot genade om in diens van sy koninkryk te mag staan. My bede is daarom dat hierdie publikasie sy Naam sal eer, sy kerk sal bou en sy koninkryk sal dien.

\section{Etiek}

Ek kan nie onthou wat my belangstelling vir die vak etiek gaande gemaak het nie. Die Here loop maar met elkeen van ons 'n pad wat $\mathrm{Hy}$ goeddink. "'n Mens beplan sy pad, maar die Here bepaal hoe hy loop."

Ek wil graag by hierdie geleentheid enkele opmerkings maak, nié oor die inhoud van die boek self nie, maar oor die beoefening van die vak etiek én oor die feit dat etiek een van die moeilikste vakke in die teologiese vakgebied is. Ek noem 'n aantal apsekte.

\section{- Die moeilikheidsgraad van etiese vrae}

In die etiek kom sommige van die moeilikste lewensvrae na vore wat om antwoorde vra. Vandag kom van dié lastige vrae veral in die mediese etiek na vore, byvoorbeeld kloning. Is dit moreel verantwoord dat kloning

1 In sy voordrag het die spreker hier na 'n aantal persone en instansies verwys. 
van mense plaasvind of oorskry die mens daarmee sy morele verantwoordelikheid? Ook in die politieke etiek kom moeilike vrae na vore, byvoorbeeld rondom 'n kernoorlog. Die etiese vraagstelling word dikwels soos volg geformuleer: Mág wat kán? Ons weet dat die Bybel geen teksboek vir die etiek is in die sin dat daarin direkte antwoorde op alle etiese vrae verskaf word nie. Die Bybel bevat egter die groot riglyne vir verantwoorde etiese beslissings. Hiervoor is die leiding van die Gees en die insigte van ander gelowiges onmisbaar.

\section{- Die gevaar van goedkoop antwoorde}

Hierdie gevaar is veral aktueel vir die gereformeerde teologie met sy sterk apologetiese inslag. Wanneer die etiek met groot vrae gekonfronteer word, is die maklikste en veiligste weg dikwels om nee te sê, maar dit is nie noodwendig die korrekte weg nie. In die sestigerjare van die vorige eeu is die regmatigheid van reënmaak (wolketap) en hartoorplantings heftig bespreek en die aanvanklike antwoorde was oorwegend negatief. Vandag dink niemand meer daaraan om hierdie sake te bevraagteken nie.

\section{- Die tyd vir antwoorde is min}

Wanneer daar skielik 'n etiese vraagstelling op tafel kom, vra dit om 'n onmiddellike antwoord en is daar nie veel tyd vir besinning beskikbaar nie. As ek vir 'n oomblik weer na die mediese etiek kan terugkeer: die mediese tegniek het ver onder die mediese etiek uitbeweeg en die morele leiding kom dikwels veels te laat. Dit is nie moeilik om die jawoord te gee as 'n bepaalde ontwikkeling reeds algemeen aanvaar word nie (bv. hartoorplantings), maar dis baie moeilik om in die oomblik van waarheid die regte rigting aan te wys.

\section{- Die beperktheid van menslike insig}

Die filosowe praat in hierdie opsig van kenteoretiese voorlopigheid. Al ons (ook teologiese) kennis en insig is ménslik en daarom beperk en voorlopig van aard. Ons ken ten dele, ook in die etiek. Daarom dra ons etiese antwoorde 'n voorlopige karakter. As die Gees van die Here ons lei, kan die etiek natuurlik ook op 'n tweede manier vóór-lopig wees in die sin van voorloop, van pad oopmaak, van leiding gee.

\section{- Die vrees vir seerkry}

Wanneer daar op 'n moeilike etiese vraagstelling 'n antwoord gegee moet word wat teen die algemene opinie of die tradisie ingaan, is daar die voortdurende vrees om geëtiketteer en geïsoleer te word en as persona non grata beskou te word. Dit is nie maklik om alleen te staan nie. En tog moet teoloë die moed hê om eerder alleen vír die waarheid te 
staan as saam met die massa, maar téén die waarheid - daaraan het die Deense filosoof Kierkegaard ons telkens in sy geskrifte herinner.

\section{- Die bewustheid van eie tekortkomings}

Die etikus staan voortdurend voor die vraag: klop my leer en lewe, my dogmatiek en etiek? Hier geld die spreekwoord: "Practise what you preach". Dit is goedkoop en maklik om die mooiste dinge te skryf en die pragtigste antwoorde te gee, maar indien jou persoonlike lewe en besluitneming jou mooi woorde weerspreek, is dit van nul en gener waarde. Die etikus weet maar alte goed van hierdie dialektiese spanning in sy lewe, van wat hy doen én wat hy behóórt te doen, van die ou karakter en nuwe karakter wat in sy gemoed woed.

Is etiek dalk die moeilikste teologiese dissipline? Dít sou sekerlik 'n oordrewe stelling wees, maar niemand sal ontken dat in die etiek van die moeilikste teologiese vrae aan die orde gestel word nie. Juis daarom kan die etiek, en die etikus, nie leef en werk sonder die genade van die goeie God, sonder die lig van die Woord van God, sonder die leiding van die Gees van God en sonder die voortdurende kritiese begeleiding van die gemeenskap van die heiliges nie. 